\title{
DIAGNÓSTICO DA ARBORIZAÇÃO URBANA DA ÁREA CENTRAL DE SANTA MARIA DE JETIBÁ, ES
}

\author{
Luciene Laurett ${ }^{1}$ \\ Jackson Roberto Dias Ribeiro \\ Mayara N.O. Clemes ${ }^{3}$
}

Resumo: A arborização possui grande importância nos centros urbanos, sendo responsável por vários benefícios ambientais e sociais que melhoram a qualidade de vida da população. Porém, arborizar uma cidade não é simplesmente plantar árvores em ruas, praças e jardins. A vegetação em áreas urbanas contribui para a estabilidade climática e para a melhoria da qualidade do ar, para a redução da poluição sonora e visual e, consequentemente, para a melhoria da saúde física e mental da população considerando os inúmeros benefícios resultantes da arborização urbana, este trabalho tem como objetivo identificar as espécies utilizadas na arborização do município de Santa Maria de Jetibá, ES e quantificar as espécies nativas e exóticas utilizadas em sua composição. Por meio deste estudo foi possível identificar a baixa diversidade arbórea na área estudada, havendo predominância da espécie Licania tomentosa a qual corresponde por $63,87 \%$ das arbóreas implantadas. Concluiu-se, portanto, que a utilização de indivíduos arbóreos da mesma espécie, não representa embelezamento na arborização, levando à característica de monotonia, fato que confirma a falta de planejamento na arborização urbana da área estudada.

Palavras-chave: Diversidade arbórea; Inventário; Espécies nativas.

\footnotetext{
${ }^{1}$ Mestranda do Programa de Pós-graduação em Agricultura Tropical, Universidade Federal do Espírito Santo (UFES), Brasil. E-mail: lucienelaurett@gmail.com.

2 Mestrando do Programa de Pós-graduação em Agricultura Tropical, Universidade Federal do Espírito Santo (UFES), Brasil. E-mail: jacksonrdr@msn.com.

${ }^{3}$ Tecnóloga em silvicultura, Faculdade da Região Serrana, Brasil. E-mail: nadiaclemes@gmail.com.
} 